This is the author's final, peer-reviewed manuscript as accepted for publication. The publisher-formatted version may be available through the publisher's web site or your institution's library.

\title{
Heteroepitaxial B12As2 on silicon substrates
}

Z. Xu, J. H. Edgar, S. Speakman

\section{How to cite this manuscript}

If you make reference to this version of the manuscript, use the following information:

Xu, Z., Edgar, J. H., \& Speakman, S. (2006). Heteroepitaxial B12As2 on silicon substrates. Retrieved from http://krex.ksu.edu

\section{Published Version Information}

Citation: Xu, Z., Edgar, J. H., \& Speakman, S. (2006). Heteroepitaxial B12As2 on silicon substrates. Journal of Crystal Growth, 293(1), 162-168.

Copyright: Crown Copyright @ 2006 Published by Elsevier B.V.

Digital Object Identifier (DOI): doi:10.1016/j.jcrysgro.2006.04.092

Publisher's Link: http://www.sciencedirect.com/science/article/pii/S0022024806004490

This item was retrieved from the K-State Research Exchange (K-REx), the institutional repository of Kansas State University. K-REx is available at http://krex.ksu.edu 


\title{
Heteroepitaxial $\mathrm{B}_{12} \mathrm{As}_{2}$ on Silicon Substrates
}

\author{
Z. Xu' ${ }^{\mathrm{a}}$, J.H. Edgar ${ }^{\mathrm{a}, *}$, S. Speakman ${ }^{\mathrm{b}}$ \\ ${ }^{a}$ Department of Chemical Engineering, Kansas State University, Manhattan, KS- 66506, USA \\ ${ }^{b}$ High Temperature Materials Laboratory, Oak Ridge National Laboratory, Oak Ridge, TN-37831, USA
}

\begin{abstract}
The morphology and crystal structure of rhombohedral $\mathrm{B}_{12} \mathrm{As}_{2}$ thin films prepared by chemical vapor deposition on $\mathrm{Si}(100), \mathrm{Si}$ (110) and $\mathrm{Si}$ (111) substrates were examined. For short depositions, 30 seconds at $1300{ }^{\circ} \mathrm{C}$, the $\mathrm{B}_{12} \mathrm{As}_{2}$ nucleated in patterns that were unique to each substrate orientation, probably due to variations in the surface atomic structure and surface activation energy of the substrates. Small square domains, one dimensional straight lines, and irregular lines were the representative morphologies on $\mathrm{Si}$ (100), Si (111) and Si (110), respectively. For long deposition, 30 minutes at $1300{ }^{\circ} \mathrm{C}$, continuous thin films of $\mathrm{B}_{12} \mathrm{As}_{2}$ formed with distinct morphologies also dependent on the orientation of the substrates. "Cross", "wire" and "chain" morphologies were formed on the $\mathrm{Si}$ (100), Si (111) and $\mathrm{Si}(110)$ substrates, respectively. X-ray diffraction showed that the $\mathrm{B}_{12} \mathrm{As}_{2}$ films had the following predominant oriented textures: $\mathrm{B}_{12} \mathrm{As}_{2}(110)$ on $\mathrm{Si}(100)$, $\mathrm{B}_{12} \mathrm{As}_{2}$ (101) on $\mathrm{Si}(111)$, and $\mathrm{B}_{12} \mathrm{As}_{2}(001)$ on $\mathrm{Si}(110)$. The in-plane orientations of the $\mathrm{B}_{12} \mathrm{As}_{2}$ films as determined by XRD pole figures, is also reported.
\end{abstract}




\section{Introduction}

The distinctive structure and properties of rhombohedral semiconducting borides make them potentially useful for beta cells, devices for converting beta radiation energy into electricity [1]. There are two rhombohedral boron-rich wide bandgap semiconductors: $\mathrm{B}_{12} \mathrm{As}_{2}(\mathrm{Eg}=3.47 \mathrm{eV})$ and $\mathrm{B}_{12} \mathrm{P}_{2}(\mathrm{Eg}=3.35 \mathrm{eV})$. The structure of these borides consist of 12-boron-atom icosahedra located at the corners of a rhombohedral unit cell and two-atom As-As or P-P chains spanning the unit cell body diagonal aligned with the $c$-axis $[2,3,4]$. Boron atoms are located at the 12 vertices of each icosahedra, and the icosahedra are bound by boron-boron bonds to form the $\alpha$-rhombohedral boron structure. The As-As or P-P two-atom chains are surrounded by, and bonded to neighboring boron icosahedra. The internal and external bondings of the boron icosahedra are very strong and stiff $[3,5]$. An attractive property of these borides is that they "self-heal" from radiation damage; radiation-induced boron interstitials and vacancies rapidly recombine [6].

The literature on the growth of $\mathrm{B}_{12} \mathrm{As}_{2}$ crystals is very limited [7-10]. Recently, $\mathrm{B}_{12} \mathrm{As}_{2}$ thin films have been deposited on $6 \mathrm{H}-\mathrm{SiC}(0001)$ substrates at process temperatures up to $1400{ }^{\circ} \mathrm{C}$ [11-14]. Silicon is an alternative substrate worth consideration for the $\mathrm{B}_{12} \mathrm{As}_{2}$ thin film deposition, since Si substrates offer several advantages over SiC, including much lower costs, the availability of larger area substrates and the possibility of combining $\mathrm{Si}$ logic circuits with boride power sources on a single substrate. Previous results showed that the $\mathrm{B}_{12} \mathrm{As}_{2}$ films formed on $\mathrm{Si}$ substrates at $1150{ }^{\circ} \mathrm{C}$ by chemical vapor deposition were amorphous or polycrystalline [8-10]. The orientation relationships obtained by Hirayama et 
al [8] were $\mathrm{B}_{12} \mathrm{As}_{2} \quad(110) \quad<1 \overline{1} 0>\quad / / \quad \mathrm{Si}(100)<100>, \quad \mathrm{B}_{12} \mathrm{As}_{2}(110)<1 \overline{1} 0>$ $/ / \operatorname{Si}(110)<1 \overline{1} 0>$, and $\mathrm{B}_{12} \mathrm{As}_{2}(211)<11 \overline{2}>/ / \mathrm{Si}(111)<\overline{1} 01>$.

In this article the nucleation behavior, the deposit morphology, and the orientation texture of $\mathrm{B}_{12} \mathrm{As}_{2}$ thin films formed on the three most common silicon substrates orientations are described. The $\mathrm{B}_{12} \mathrm{As}_{2}$ thin films were prepared by chemical vapor deposition at a higher process temperature than in previous studies employing silicon substrates, $1300{ }^{\circ} \mathrm{C}$. At this deposition temperature textured polycrystalline thin films were deposited. The preferred orientations were determined by x-ray diffraction techniques.

\section{Experimental}

$\mathrm{B}_{12} \mathrm{As}_{2}$ thin films were deposited in an inductively heated horizontal quartz CVD reactor. The source gases were $1 \% \mathrm{~B}_{2} \mathrm{H}_{6}$ in $\mathrm{H}_{2}$ and $2 \% \mathrm{AsH}_{3}$ in $\mathrm{H}_{2}$. The flow rates of $\mathrm{B}_{2} \mathrm{H}_{6}$ and $\mathrm{AsH}_{3}$ source gases were $100 \mathrm{sccm}$ and $10 \mathrm{sccm}$, respectively. The carrier gas was palladium membrane purified hydrogen with a constant flow rate of $2.5 \mathrm{slm}$. The $\mathrm{Si}$ substrates, including Si (100), Si (110) and Si (111), were etched with the HF solution, ultrasonically degreased by the acetone and methanol solutions, and dried using filtered nitrogen. The substrates then were placed inside a hollow tantalum carbide coated graphite susceptor. The susceptor/substrate temperature was measured by a thermocouple. Films were deposited at $1300{ }^{\circ} \mathrm{C}$ and a constant pressure of 500 torr. 
The nucleation layers were produced by depositing on the silicon substrates at $1300{ }^{\circ} \mathrm{C}$ for 30 seconds. The distribution and the shape of the $\mathrm{B}_{12} \mathrm{As}_{2}$ nuclei were thus studied by atomic force microscopy (AFM). The thicker (approximately $1 \mu \mathrm{m}$ ) $\mathrm{B}_{12} \mathrm{As}_{2}$ thin films were formed by 30 minute depositions at $1300{ }^{\circ} \mathrm{C}$. The morphology of these $\mathrm{B}_{12} \mathrm{As}_{2}$ deposits was characterized by scanning electron microscopy (SEM).

The theta-two theta XRD measurements were taken at the Kansas State University, using a Bruker AXS D8 ADVANCE XRD instrument. To analyze the texture of the resultant $\mathrm{B}_{12} \mathrm{As}_{2}$ films, $\mathrm{x}$-ray pole figures were collected at Oak Ridge National Laboratories using a Scintag PTS 4-axis diffractometer with a $5 \times 2$ grid: the rotation angle (PHI) was changed from 0 to 355 degrees in 5 degree increments, and the tilt angle (CHI) was changed from 0 to the end value in 2 degree increments (while the diffraction angle, two theta, was held fixed for the reflection of interest).

\section{Results and Discussion}

\section{(1) Morphology analysis (by AFM and SEM)}

Atomic force micrographs of the $\mathrm{B}_{12} \mathrm{As}_{2}$ nucleation layers, scanning electron micrographs of the continuous $\mathrm{B}_{12} \mathrm{As}_{2}$ films, and schematic diagrams showing the position of atoms for the silicon substrates are presented for $\operatorname{Si}(100), \operatorname{Si}(111)$, and $\operatorname{Si}(110)$ in Figures 1-3 respectively. The height of the nuclei were around $30 \sim 50 \mathrm{~nm}$ on all substrates. On Si (100), the nuclei were uniformly distributed, and they were about $30 \sim 35 \mathrm{~nm}$ high and 200 $\mathrm{nm}$ in diameter (Fig 1(a)); on $\mathrm{Si}$ (111), the nuclei were highly aligned in one direction (Fig 
2(a), and they were about $40 \sim 50 \mathrm{~nm}$ high and $200 \mathrm{~nm}$ wide; and on Si (110), a "chain"-like nucleation layers were very clear, with a height of $50 \mathrm{~nm}$ and a chain width of around $500 \mathrm{~nm}$.

Examining the thicker $\mathrm{B}_{12} \mathrm{As}_{2}$ deposits by SEM revealed morphologies with symmetries characteristic of the underlying substrates. On $\mathrm{Si}(100)$ substrates (Fig. 1b) the $\mathrm{B}_{12} \mathrm{As}_{2}$ grains are rod-like with a flat surface parallel to the film surface. The rods seem to have two dominant orientations with grains rotated by $90^{\circ}$ with respect to each other. The film on Si(111) substrates (Fig. 2b) features highly-faceted rods. Because the grains are rods, three dominant orientations can clearly be seen. However, one orientation is more dominant (running from bottom right to upper-left in Fig. 2b). The pronounced faceting seen in the $\mathrm{B}_{12} \mathrm{As}_{2}$ film on $\mathrm{Si}(111)$ (Fig. 2b) suggests the corner of a hexagonal structure, and is significantly different than the smoother films seen on $\operatorname{Si}(100)$ and $\operatorname{Si}(110)$ substrates. Films on $\mathrm{Si}(110)$ are flat platelets that do not have one direction longer than another (Fig. 3b). This morphology is characteristic of a hexagonal material with its basal plane parallel to the film's surface.

As seen the AFM and SEM images, the variation of the morphology of the $\mathrm{B}_{12} \mathrm{As}_{2}$ thin films could be a consequence of the differences in the nucleation morphology. Moreover, the distinct nucleation morphology and orientations on these substrates is probably due to the variation in the surface atomic structure and the surface activation energy of the substrates. Shown in Figures 1c, 2c, and 3c are the planar atomic configurations along Si [100], Si [111] and Si [110] respectively [15]. In Fig. 1c and 3c the Si (100) and Si (110) 
unit planes consist of the atoms illustrated with solid circles, while the Si (111) plane is made up of the atoms illustrated with solid and open circles in Fig. 2c. The Si atoms in the (100) plane form a "cross"; the Si atoms in the (111) form a "triangle"; and the Si atoms in the (110) form a "chain". The substrate surface atomic configurations have dominated the subsequent $\mathrm{B}_{12} \mathrm{As}_{2}$ nucleation and film growth.

\section{(2) Structure analysis (by XRD theta-two theta scanning)}

In Fig. 4, theta-two theta XRD patterns are presented from the $\mathrm{B}_{12} \mathrm{As}_{2}$ films deposited on the three types of silicon substrates, along with a XRD pattern for a randomly oriented $\mathrm{B}_{12} \mathrm{As}_{2}$ powder for comparison. The XRD patterns show that $\mathrm{B}_{12} \mathrm{As}_{2}(110)$ is a preferred orientation on $\mathrm{Si}$ (100) (Fig. 4a), but $\mathrm{B}_{12} \mathrm{As}_{2}(101), \mathrm{B}_{12} \mathrm{As}_{2}(003 / 012), \mathrm{B}_{12} \mathrm{As}_{2}(024 / 211)$ and $\mathrm{B}_{12} \mathrm{As}_{2}(125 / 220)$ peaks are also apparent; this indicates that there is some degree of random orientation in the grains of the film. On $\mathrm{Si}(111)$, both $\mathrm{B}_{12} \mathrm{As}_{2}(101)$ and $\mathrm{B}_{12} \mathrm{As}_{2}$ (104/021) are preferred orientations with another observable peak of $\mathrm{B}_{12} \mathrm{As}_{2}(205 / 300)$ (Fig 4b). On Si (110), $\mathrm{B}_{12} \mathrm{As}_{2}(003), \mathrm{B}_{12} \mathrm{As}_{2}(006)$, and $\mathrm{B}_{12} \mathrm{As}_{2}$ (009) are displayed, which indicates that the $\mathrm{B}_{12} \mathrm{As}_{2}$ crystals are $c$-axis aligned with their (00n) planes paralleling to the (110) plane of the substrate (Fig 4c). The $c$-axis alignment of the $\mathrm{B}_{12} \mathrm{As}_{2}$ thin films on $\mathrm{Si}(110)$ is the same as that on $6 \mathrm{H}-\mathrm{SiC}(0001)$ substrates $[11,14]$. The aforementioned orientation relationships of $\mathrm{B}_{12} \mathrm{As}_{2}$ crystals on silicon substrates are different from the reported data in the literature [8], which is probably due to the $150{ }^{\circ} \mathrm{C}$ higher growth temperatures. 


\section{(3) Texture analysis (by XRD pole figures)}

XRD pole figures were applied to analyze the texture of the resultant $\mathrm{B}_{12} \mathrm{As}_{2}$ thin films on the various silicon substrates. Pole figures provide information about the range of alignments for specific crystals within the film.

The $\mathrm{B}_{12} \mathrm{As}_{2}$ thin film exhibited the strongest epitaxy when deposited on a $\operatorname{Si}(110)$ substrate. Figure 5 compares the pole figures of the $\{003\}$ and $\{012\}$ peaks at 2theta $=33.48^{\circ}$ for $\mathrm{B}_{12} \mathrm{As}_{2}$ and of the (311) Si peak at 2 theta $=88.717^{\circ}$. The intense (003) peak at $\mathrm{CHI}=0^{\circ}$ indicated that the [003] direction of $\mathrm{B}_{12} \mathrm{As}_{2}$ was parallel to the [110] of the Si substrate and that the basal plane of the hexagonal unit cell was parallel to (110) surface plane of the Si substrate. This is consistent with the platelet microstructure observed in the SEM micrograph (Fig $3 b$ ) and the $\{00 \mathrm{n}\}$ peaks observed in the theta-2theta diffraction pattern (Fig 4c). There were two sets of $\{012\}$ peaks at $\mathrm{CHI}=48^{\circ}$, indicating that there were two orientations of $\mathrm{B}_{12} \mathrm{As}_{2}$ crystallites related by a $180^{\circ}$ rotation about the [003]. These two sets of in-plane rotational variants, arising from the anti-symmetric triangles at opposing faces of a boron icosahedron [16], have also been observed in $\mathrm{B}_{12} \mathrm{As}_{2}$ films grown on $6 \mathrm{H}-\mathrm{SiC}$ substrates [14], and are due to the similar hexagonal surface structure of $\mathrm{Si}(110)$ and (0001) $6 \mathrm{H}-\mathrm{SiC}$ [17]. As illustrated in Fig. 5, these two orientations are

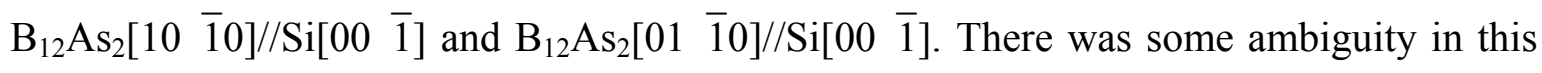
determination, however. When the $\mathrm{B}_{12} \mathrm{As}_{2}\left[\begin{array}{lll}10 & \overline{1} 0\end{array}\right]$ is parallel to $\operatorname{Si}\left[\begin{array}{ll}00 & \overline{1}\end{array}\right]$, the $\mathrm{B}_{12} \mathrm{As}_{2}\left[\begin{array}{ll}01 & \overline{1} 0\end{array}\right]$ is consequently misaligned from the $\operatorname{Si}\left[\begin{array}{ll}1 & \overline{1}\end{array}\right]$ by only $5^{\circ}$. Given that the pole figure was 
collected in $5^{\circ}$ steps about the rotation axis Phi, this means that it is possible that the two orientations were instead $\mathrm{B}_{12} \mathrm{As}_{2}\left[\begin{array}{lll}10 & \overline{10}\end{array}\right] / / \mathrm{Si}\left[\begin{array}{ll}\overline{1} 1 & \overline{1}\end{array}\right]$ and $\mathrm{B}_{12} \mathrm{As}_{2}\left[\begin{array}{ll}01 & \overline{1} 0\end{array}\right] / / \mathrm{Si}\left[\begin{array}{ll}\overline{1} 1 & \overline{1}\end{array}\right]$.

Each $\{012\}$ diffraction peak in the pole figure actually consisted of a peak doublet produced by a tilt about the axis defined by the $\operatorname{Si}[\overline{1} 10]\left(\mathrm{PHI}=140^{\circ}\right)$ and $\operatorname{Si}\left[\begin{array}{ll}1 & 10\end{array}\right]$ $\left(\mathrm{PHI}=320^{\circ}\right)$. The cause for this peak splitting, whether a step in the Si substrate or a true misorientation of some $\mathrm{B}_{12} \mathrm{As}_{2}$ crystallites, is not known.

Shown in Fig. 6 is the pole figure of a $\mathrm{B}_{12} \mathrm{As}_{2}$ thin film on a $\mathrm{Si}(100)$ substrate, displaying the $\{101\}$ peaks at $2 \theta=27.21^{\circ}$. There were four peaks at $\mathrm{CHI}=37^{\circ}$ and at $\mathrm{CHI}=66^{\circ}$. The peaks at $\mathrm{CHI}=37^{\circ}$ corresponded to $\{101\}$ peaks produced by grains in which the film's $\mathrm{B}_{12} \mathrm{As}_{2}(110)$ was parallel to the $\mathrm{Si}(100)$ plane of the substrate surface. The pole figure of one $\mathrm{B}_{12} \mathrm{As}_{2}$ grain with [110] normal to substrate surface would produce two $\{101\}$ diffraction peaks separated by a rotation of $180^{\circ}$; therefore, this pole figure indicated that the grains were distributed amongst two orientations related by a $90^{\circ}$ rotation. These two orientations corresponded to $\mathrm{B}_{12} \mathrm{As}_{2}\left[\begin{array}{lll}\overline{110} & \overline{2}\end{array}\right] / / \mathrm{Si}\left[\begin{array}{lll}00 & \overline{1}\end{array}\right]$ and $\mathrm{B}_{12} \mathrm{As}_{2}\left[\begin{array}{lll}1 & \overline{10} & \overline{2}\end{array}\right] / / \mathrm{Si}\left[\begin{array}{ll}00 & \overline{1}\end{array}\right]$. The other major $\mathrm{B}_{12} \mathrm{As}_{2}$ diffraction peaks observed in Fig. 6 roughly corresponded to $\mathrm{B}_{12} \mathrm{As}_{2}\{101\}$ peaks produced when $\mathrm{B}_{12} \mathrm{As}_{2}[\overline{1} 109]$ was normal to the surface; this was confirmed by the pole figure for $\mathrm{B}_{12} \mathrm{As}_{2}(003)$ which showed the $\{003\}$ peaks at a tilt of $\mathrm{CHI}=15^{\circ}$. In the pole figure for $\{101\}$ peaks, crystallites with $[\overline{1} 109]$ normal to the surface produced a peak doublet at $\mathrm{CHI}=53^{\circ}$, distributed by $\pm 4^{\circ}$ around the theoretical peak position. These crystallites also produced two broad diffraction peaks at $\mathrm{CHI}=66^{\circ}$. There were actually four sets of $\{101\}$ peaks, producing the four peak doublets observed at 
$\mathrm{CHI}=53^{\circ}$ and producing only four sets peaks at $\mathrm{CHI}=66^{\circ}$ peaks because of overlap between the diffraction peaks produced by different orientations. The peaks at $\mathrm{CHI}=66^{\circ}$ were broadened partially because each was produced by the overlap of two diffraction peaks produced by two different orientations. However, this does not account for the splitting of the peaks at $\mathrm{CHI}=53^{\circ}$ nor for all of the broadening of the peaks at $\mathrm{CHI}=66^{\circ}$; it is suspected that the grains were not perfectly aligned with $\mathrm{B}_{12} \mathrm{As}_{2}[\overline{1} 109] / / \mathrm{Si}[100]$ but rather consisted of a distribution of slightly misaligned crystallites or some other unidentified defect. The crystallites with [ $\overline{1} 109]$ normal to the surface (parallel to Si[100]) were distributed amongst four orientations related by $90^{\circ}$ rotations about $\mathrm{B}_{12} \mathrm{As}_{2}[\overline{1} 109]$ :

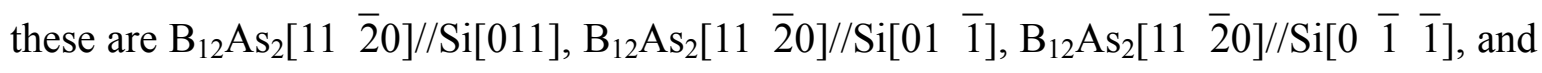
$\mathrm{B}_{12} \mathrm{As}_{2}\left[\begin{array}{ll}11 & \overline{2} 0\end{array}\right] / / \mathrm{Si}\left[\begin{array}{ll}0 & \overline{1} 1\end{array}\right]$.

The pole figures defined two distributions of crystallites, each consisting of different orientations that were related by $90^{\circ}$ rotations about the surface normal. This distribution of crystallites was consistent with the "cross" structure in the morphology orientation as shown in Fig. 1b. The lack of perfect alignment between $\mathrm{B}_{12} \mathrm{As}_{2}[\overline{1} 109]$ and $\mathrm{Si}[100]$ also allowed for the off-axis reflections, such as (003) and (024) peaks, observed in the theta-2theta X-ray diffraction pattern in Figure 4a.

Shown in Fig. 7 is the pole figure of a $\mathrm{B}_{12} \mathrm{As}_{2}$ thin film on a $\mathrm{Si}$ (111) substrate, displaying the (110) peaks at 2 theta $=43.67^{\circ}$. The two diffraction peaks corresponded to grains in which $\mathrm{B}_{12} \mathrm{As}_{2}[100]$ was aligned to the surface normal, so that $\mathrm{B}_{12} \mathrm{As}_{2}(100) / / \mathrm{Si}(111)$. These peaks dominated the pole figure with an intensity of 1500 
counts; however, these peaks were surrounded by a broad profile of intensity of $\sim 200$ counts. This broad distribution of intensity resembled a wire texture [18], possibly indicating that the $\mathrm{B}_{12} \mathrm{As}_{2}$ crystals on $\mathrm{Si}$ (111) were grown with domains as wires. In fact, as shown in the SEM image in Fig. $2(b)$, the $\mathrm{B}_{12} \mathrm{As}_{2}$ crystals were wire like with rough surface and thickness. The orientation of the film in the surface plane, with respect to the Si substrate, was not determined.

\section{Conclusions}

Crystalline $\mathrm{B}_{12} \mathrm{As}_{2}$ thin films can be obtained on $\mathrm{Si}$ (100), Si (110) and $\mathrm{Si}$ (111) substrates by chemical vapor deposition at $1300{ }^{\circ} \mathrm{C}$. The $\mathrm{B}_{12} \mathrm{As}_{2}$ nucleation behavior and film morphology of these $\mathrm{B}_{12} \mathrm{As}_{2}$ thin films is distinct due to the variation of the surface atomic configurations and activation energies of the substrates. The orientation relationships of the $\mathrm{B}_{12} \mathrm{As}_{2}$ crystals on these silicon substrates were reported showing difference from the literature. Interestingly, $c$-axis oriented $\mathrm{B}_{12} \mathrm{As}_{2}$ crystals were grown on the $\mathrm{Si}(110)$ substrate, but not on $\mathrm{Si}(100)$ and $\mathrm{Si}$ (111) substrates. On all silicon substrate studied, two or more in-plane orientations were observed. This non-unique crystal orientation on single-crystal substrates is sometimes referred to as degenerate epitaxy [19]. This is a problem which may cause the $\mathrm{B}_{12} \mathrm{As}_{2}$ films to have relatively poor electrical properties. Future efforts to explore the potential applications of $\mathrm{B}_{12} \mathrm{As}_{2}$ films will need to focus on solving this problem. 


\section{Acknowledgements}

Support for this research from the DOE EPSCoR laboratory partnership program (Grant No. DE-FG02-01ER45888) is gratefully appreciated. Research sponsored in part by the Assistant Secretary for Energy Efficiency and Renewable Energy, Office of Freedom CAR and Vehicle Technologies, as part of the High Temperature Materials Laboratory User Program, Oak Ridge National Laboratory, managed by UT-Battelle, LLC, for the US Department of Energy under contract number DE-AC05-00OR22725 is acknowledged. 


\section{References:}

[1] T.L. Aselage, and D. Emin, US Patent No. 6,479,919, Apr. 9, 2001.

[2] D. Emin, Mat. Res. Soc. Symp. Proc. 97 (1987) 3.

[3] D. Emin, Physics Today 40 (1987) 55.

[4] T. L. Aselage, D.R. Tallant, J.H. Gieske, S.B. Van Deusen, and R.G. Tissot, The Physics and Chemistry of Carbides, Nitrides and Borides (R. Freer, ed.), (1990) 97.

[5] D. Emin, J. Solid State Chem. 177 (2004) 1619.

[6] M. Carrard, D. Emin, and L. Zuppiroli, Phys. Rev. B 51 (1995) 11270.

[7] F.V. Williams, US Patent 3,413,092, Nov. 26, 1968.

[8] M. Hirayama, and K. Shohno, Jpn. J. Appl. Phys. 12 (1973) 1960.

[9] K. Shohno, M. Takigawa, and T. Nakada, J. Cryst. Growth 24/25 (1974) 193.

[10]L.A. Correia, R.C. Van Oort, and P.J. Van der Put, React. Solids 2 (1986) 203.

[11]R.H. Wang, D. Zubia, T. O'Neil, D. Emin, T. Aselage, W. Zhang, and S.D. Hersee, J. Electron. Mater. 29 (2000) 1304.

[12]R. Nagarajan, J.H. Edgar, J. Promeroy, M. Kuball, and T. Aselage, Mater. Res. Soc. Symp. Proc. 764 (2003) 283.

[13] W.M. Vetter, R. Nagarajan, J.H. Edgar, and M. Dudley, Mater. Lett. 58 (2004) 1331.

[14]R. Nagarajan, Z. Xu, J.H. Edgar, F. Baig, J. Chaudhuri, Z. Rek, E.A. Payzant, H.M. Meyer, J. Pomeroy, and M. Kuball, J. Cryst. Growth 273 (2005) 431.

[15]F. Shimura, Semiconductor Silicon Crystal Technology, Academic Press Inc., San Diego, 1989, p. 47.

[16] J.R. Michael, T.L. Aselage, D. Emin, and P.G. Kotula, J. Mater. Res. 20 (2005) 3004.

[17]Z. Xu, J.H. Edgar, L. Allard, S. Speakman, and E.A. Payzant, in preparation.

[18]U.F. Kocks, C.N. Tome, and H.-R. Wenk, Texture and Anisotropy, Cambridge University Press, Cambridge, 1998, p. 151.

[19] S.-W. Chan, J. Phys. Chem. Solids 55 (1994) 1137. 


\section{Figure Captions}

Figure 1. The a) AFM image, b) SEM image, and c) planar surface atomic configurations for $\mathrm{B}_{12} \mathrm{As}_{2}$ deposited on $\mathrm{Si}(100)$.

Figure 2. The a) AFM image, b) SEM image, and c) planar surface atomic configurations for $\mathrm{B}_{12} \mathrm{As}_{2}$ deposited on $\mathrm{Si}(111)$.

Figure 3. The a) AFM image, b) SEM image, and c) planar surface atomic configurations for $\mathrm{B}_{12} \mathrm{As}_{2}$ deposited on $\mathrm{Si}(110)$.

Figure 4. XRD patterns of the $\mathrm{B}_{12} \mathrm{As}_{2}$ thin films on the (a) Si (100), (b) Si (111), and (c) $\mathrm{Si}$ (110) substrates, and (d) the XRD pattern for a randomly oriented $\mathrm{B}_{12} \mathrm{As}_{2}$ powder.

Figure 5. XRD pole figures of a) $\mathrm{B}_{12} \mathrm{As}_{2}$ (003) and $\{012\}$ peaks, in which only the diffraction peaks from one of the crystal orientations are labeled, and $b)$ the $\mathrm{Si}\{131\}$ peaks from the $\mathrm{Si}(110)$ oriented substrate.

Figure 6. XRD pole figures of a) $\mathrm{B}_{12} \mathrm{As}_{2}\{101\}$ peaks showing labeling the peaks from one orientation when $\mathrm{B}_{12} \mathrm{As}_{2}[110]$ is normal to the surface (labels italicized) and from one orientation when $\mathrm{B}_{12} \mathrm{As}_{2}[\overline{1} 19]$ is normal to the surface (normal type), and b) the $\mathrm{Si}\{131\}$ peaks from the $\mathrm{Si}(100)$ oriented substrate.

Figure 7. XRD pole figures of $\mathrm{B}_{12} \mathrm{As}_{2}\{110\}$ peaks produced by grains with [100] normal to film surface. 

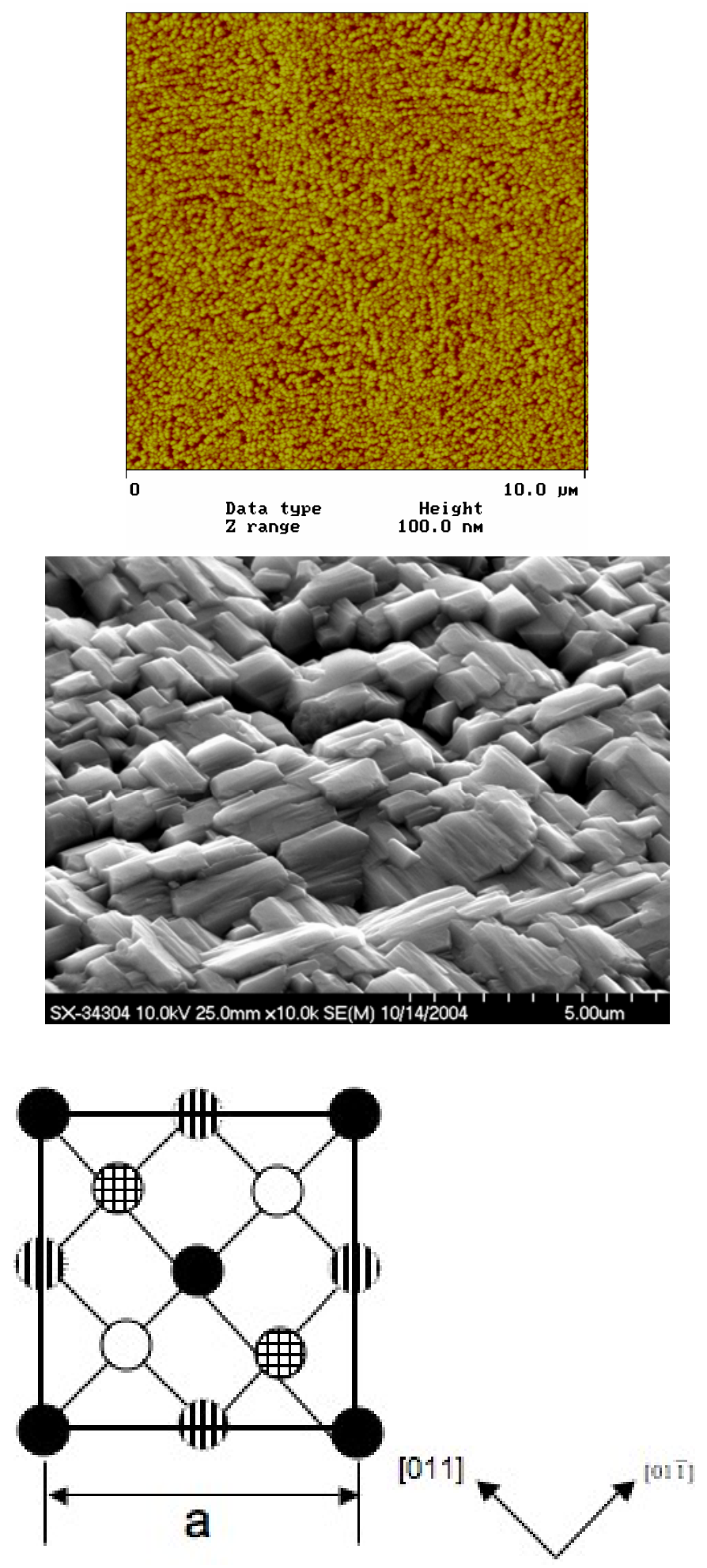

Figure 1. The a) AFM image, b) SEM image, and c) planar surface atomic configurations for $\mathrm{B}_{12} \mathrm{As}_{2}$ deposited on $\mathrm{Si}(100)$. 

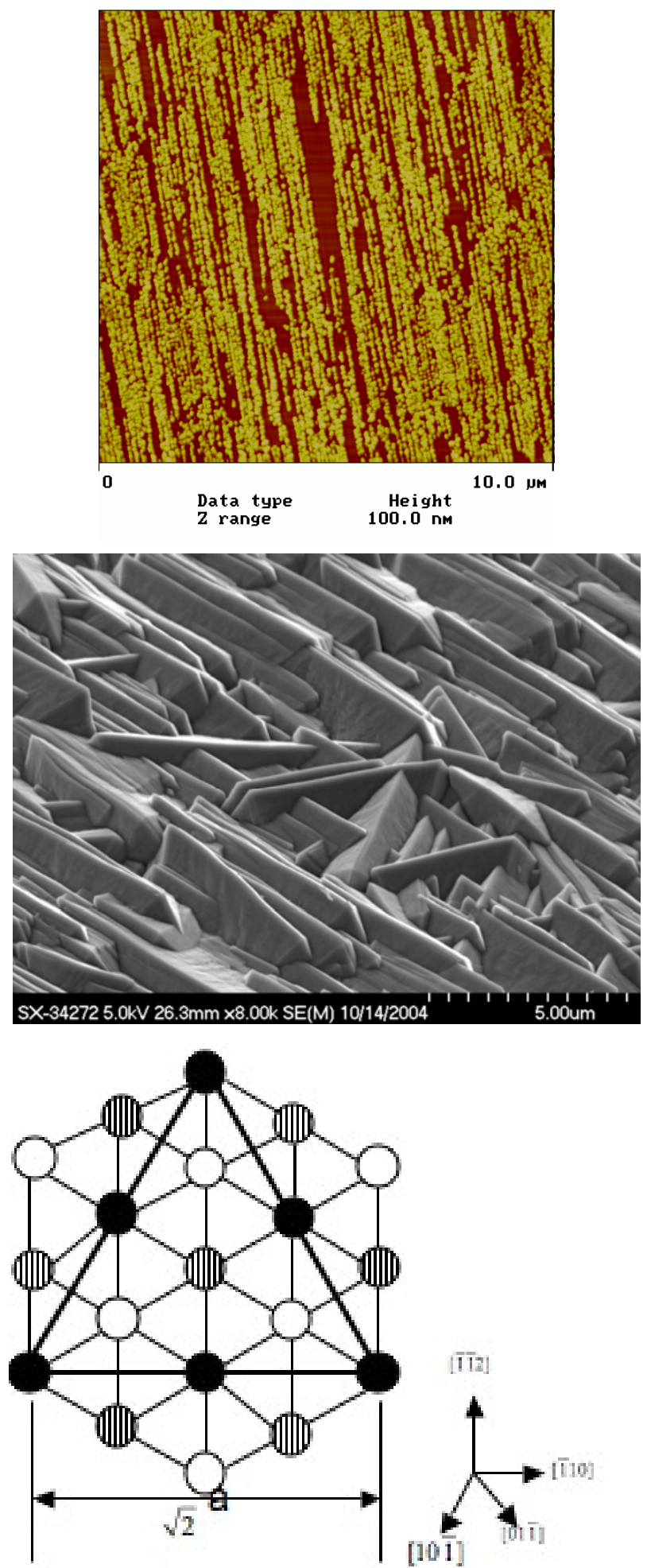

Figure 2. The a) AFM image, b) SEM image, and c) planar surface atomic configurations for $\mathrm{B}_{12} \mathrm{As}_{2}$ deposited on $\mathrm{Si}(111)$. 

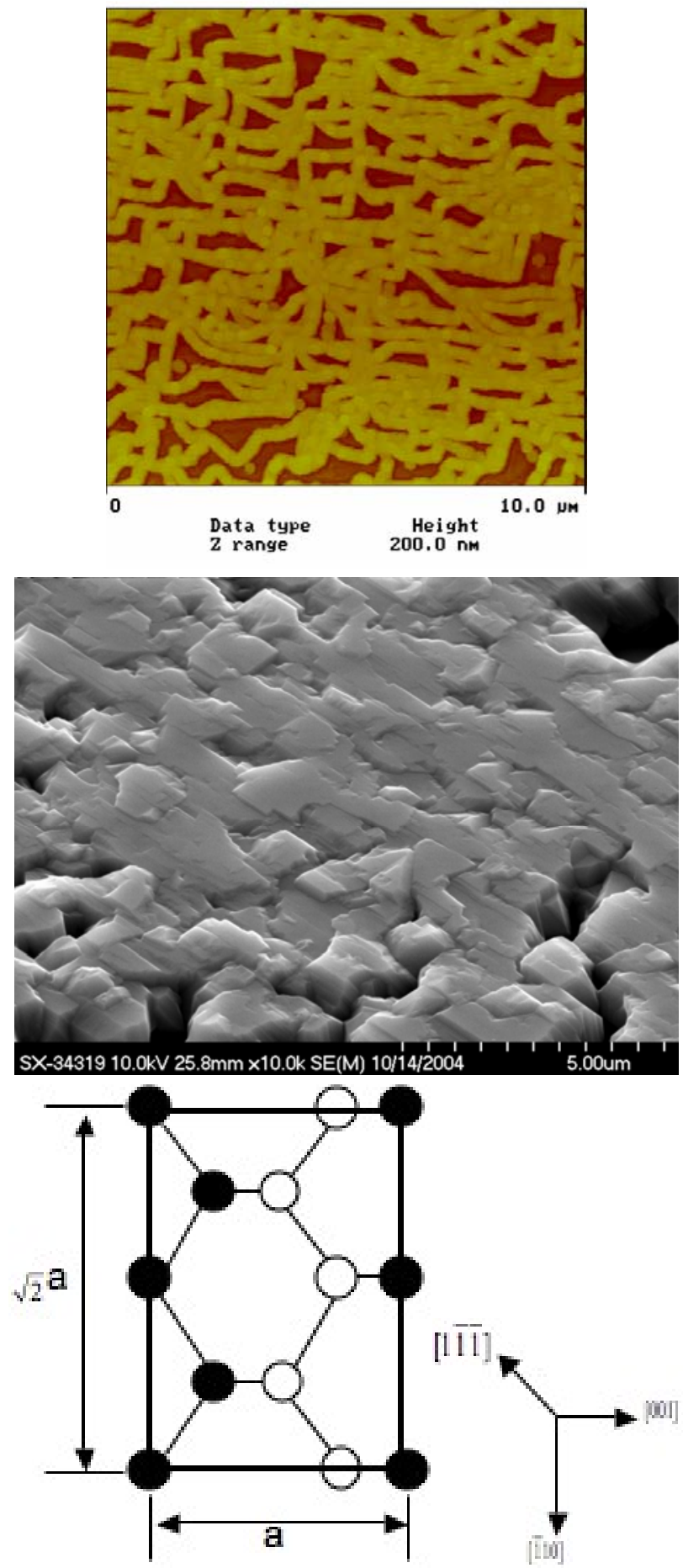

Figure 3. The a) AFM image, b) SEM image, and c) planar surface atomic configurations for $\mathrm{B}_{12} \mathrm{As}_{2}$ deposited on $\mathrm{Si}(110)$. 


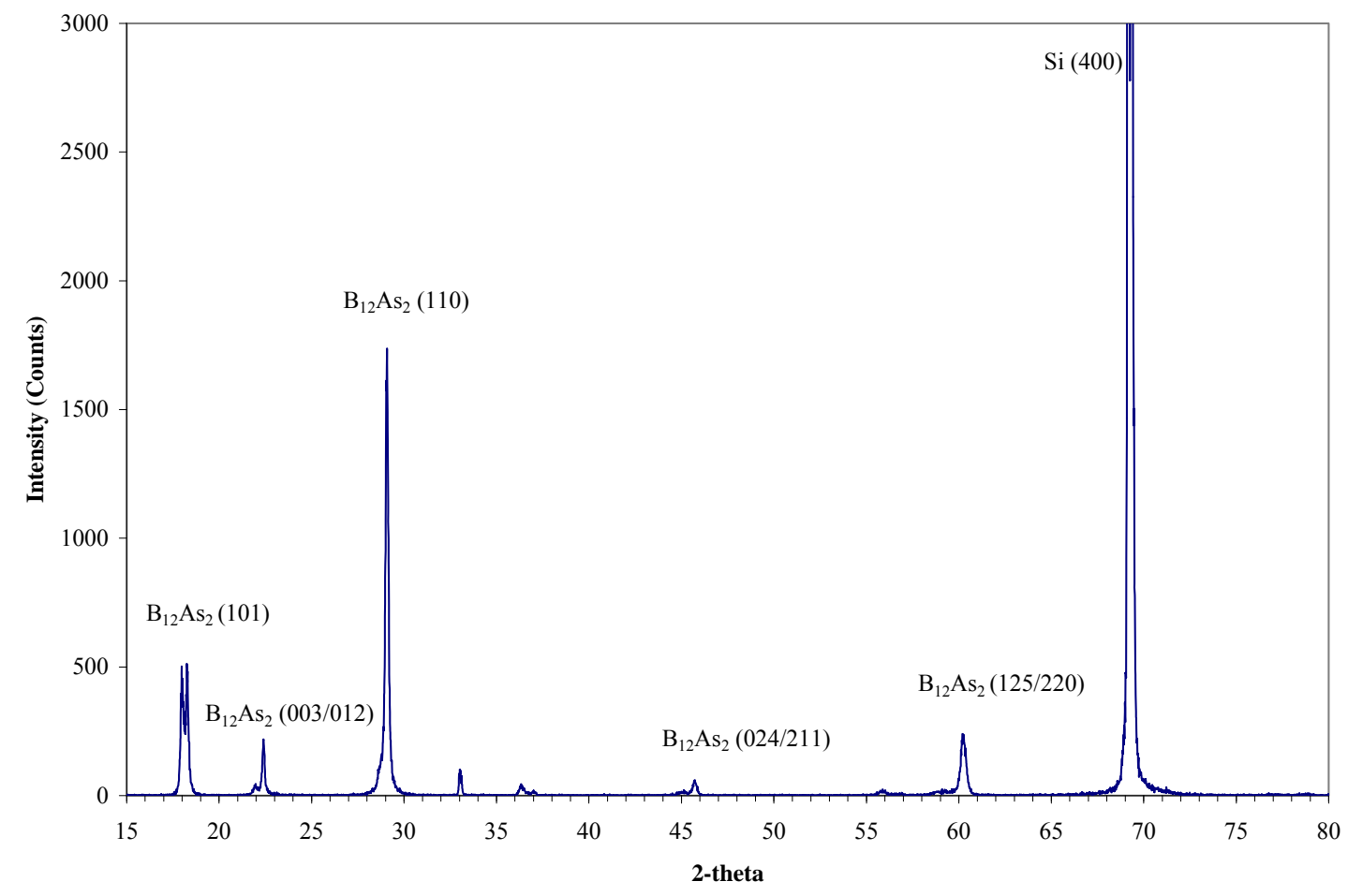

(a)

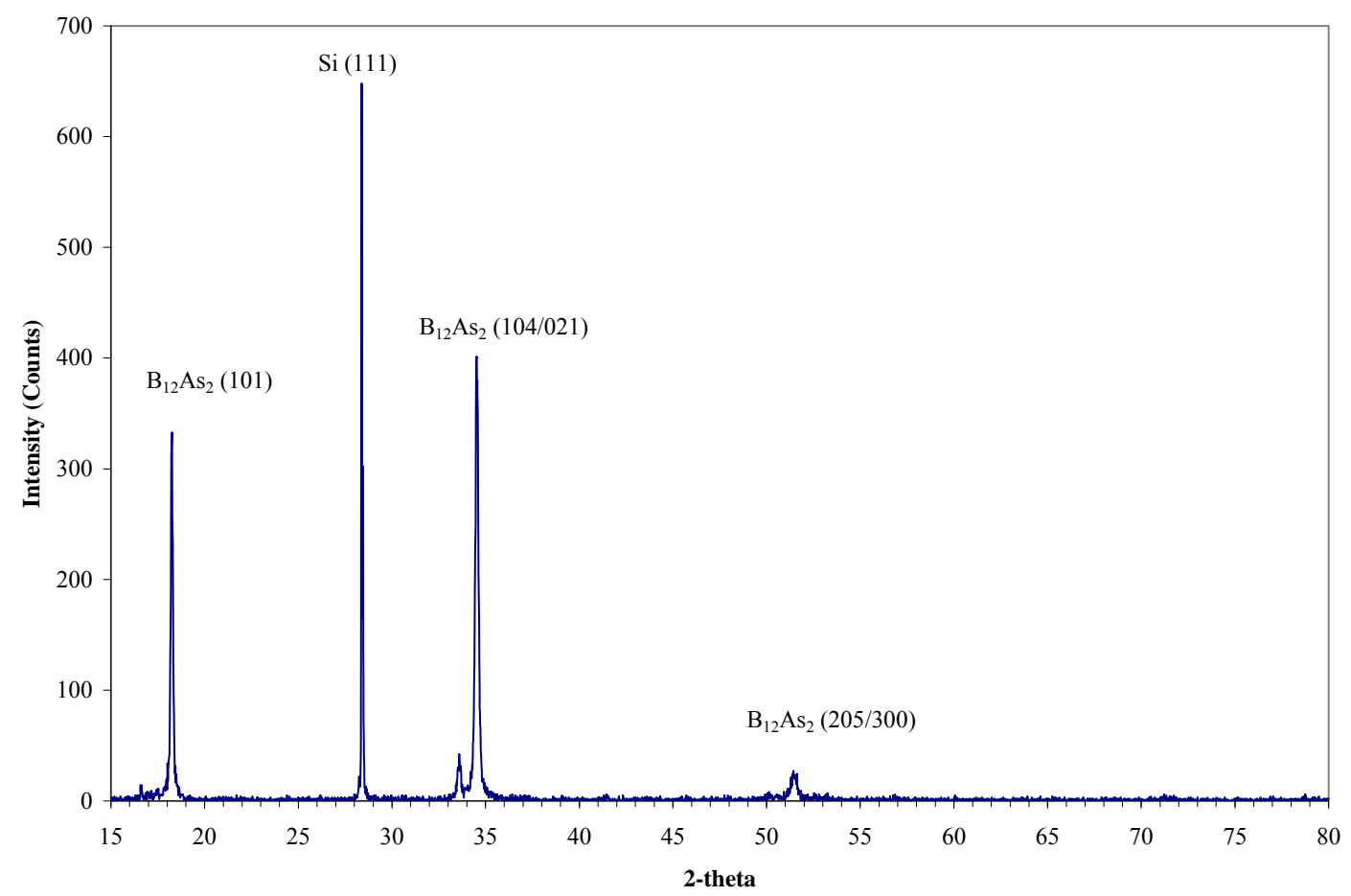

(b) 


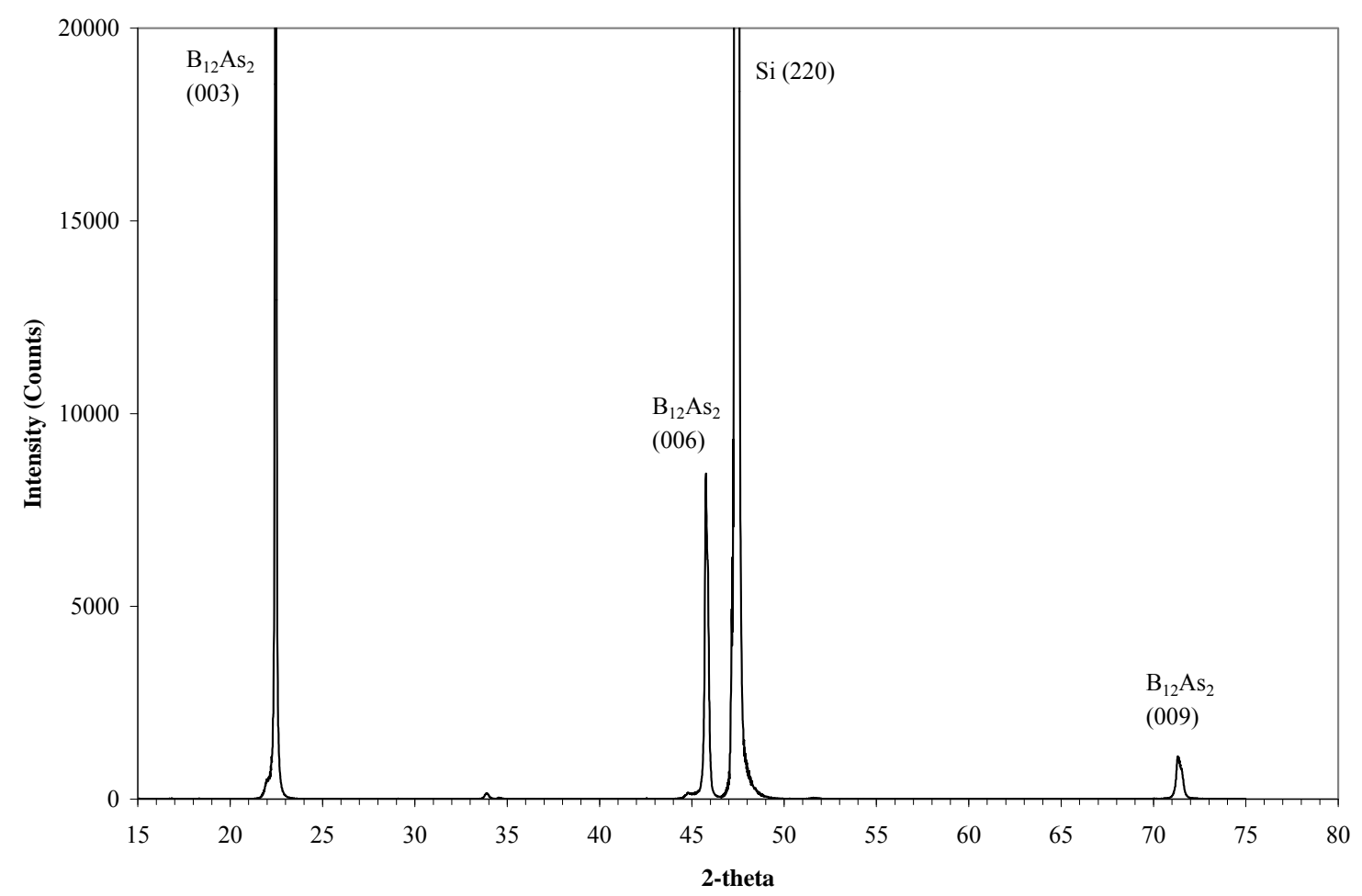

(c)

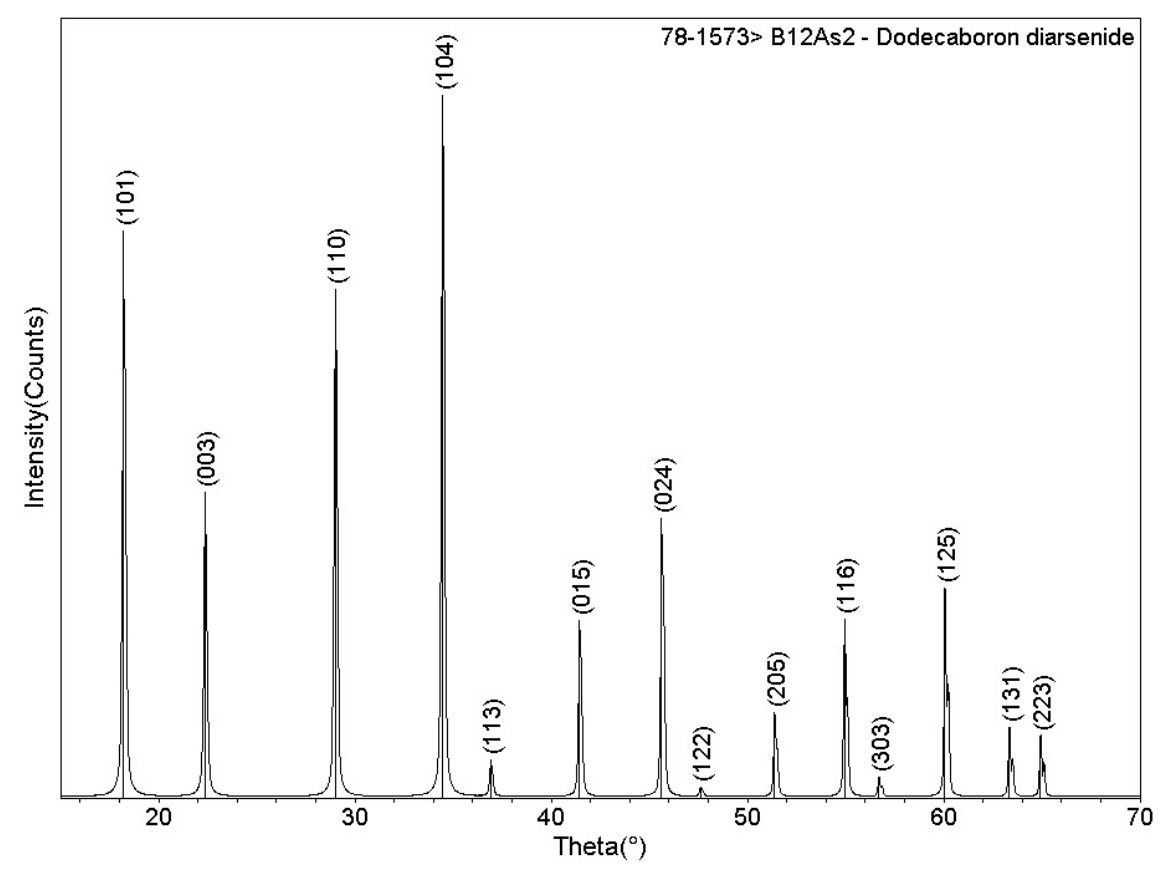


Figure 4

a)

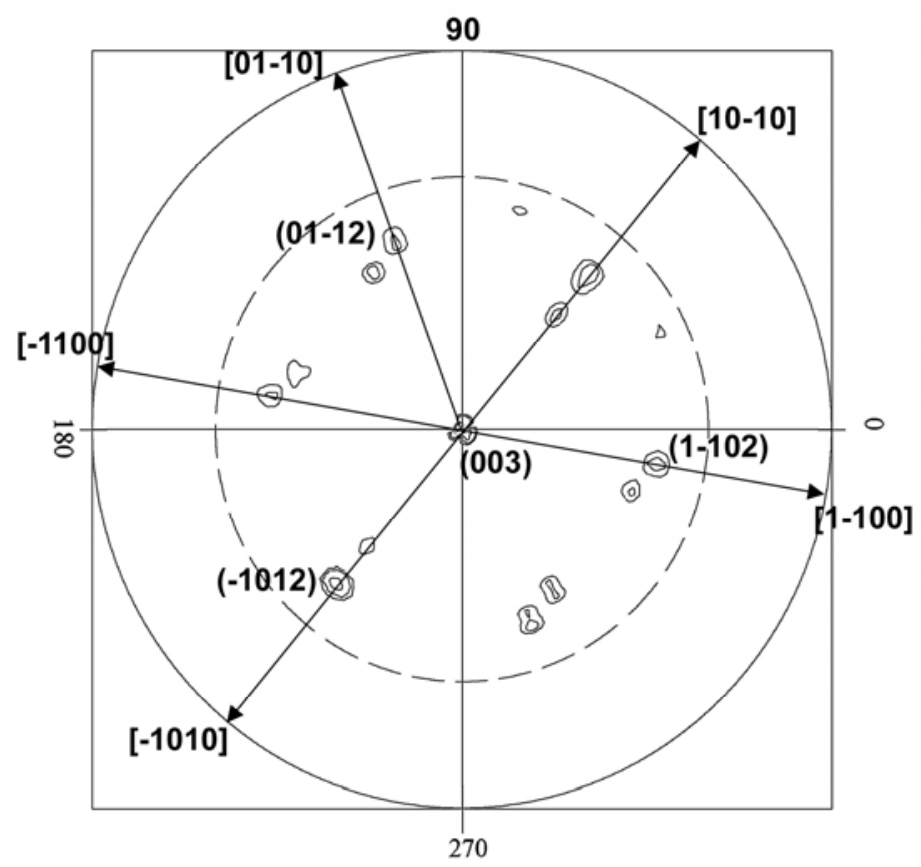

b)

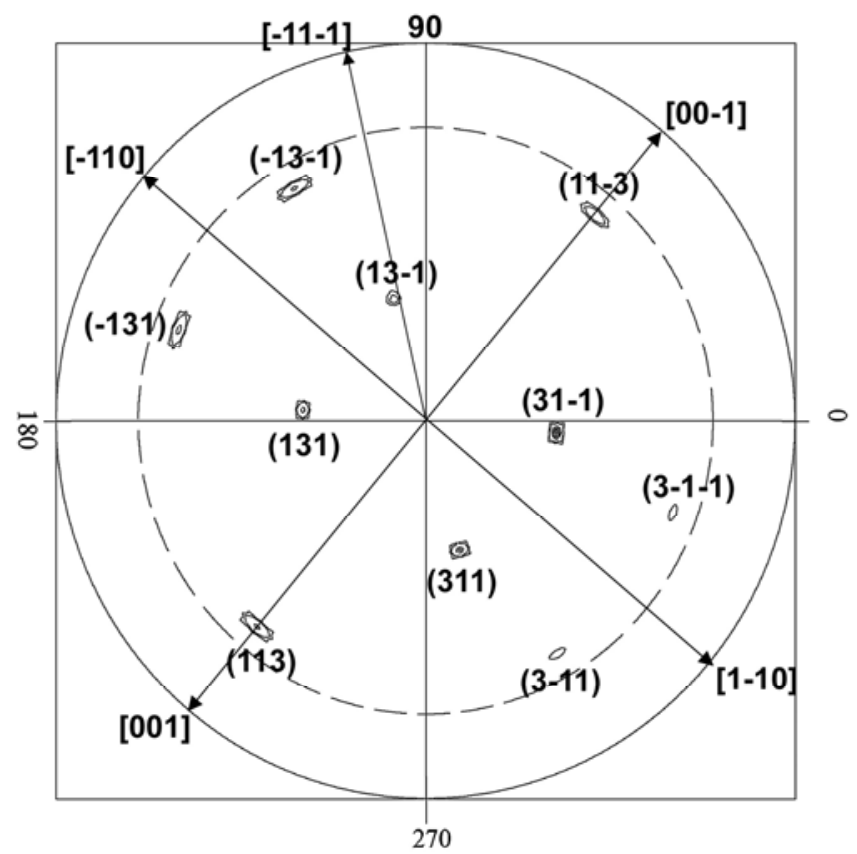

Figure 5. XRD pole figures of a) $\mathrm{B}_{12} \mathrm{As}_{2}(003)$ and $\{012\}$ peaks, in which only the diffraction peaks from one of the crystal orientations are labeled, and $b)$ the $\mathrm{Si}\{131\}$ peaks from the $\mathrm{Si}(110)$ oriented substrate. 
a)



b)



Figure 6. XRD pole figures of a) $\mathrm{B}_{12} \mathrm{As}_{2}\{101\}$ peaks showing labeling the peaks from one orientation when $\mathrm{B}_{12} \mathrm{As}_{2}[110]$ is normal to the surface (labels italicized) and from one orientation when $\mathrm{B}_{12} \mathrm{As}_{2}[\overline{1} 19]$ is normal to the surface (normal type), and b) the $\mathrm{Si}\{131\}$ peaks from the $\mathrm{Si}(100)$ oriented substrate. 


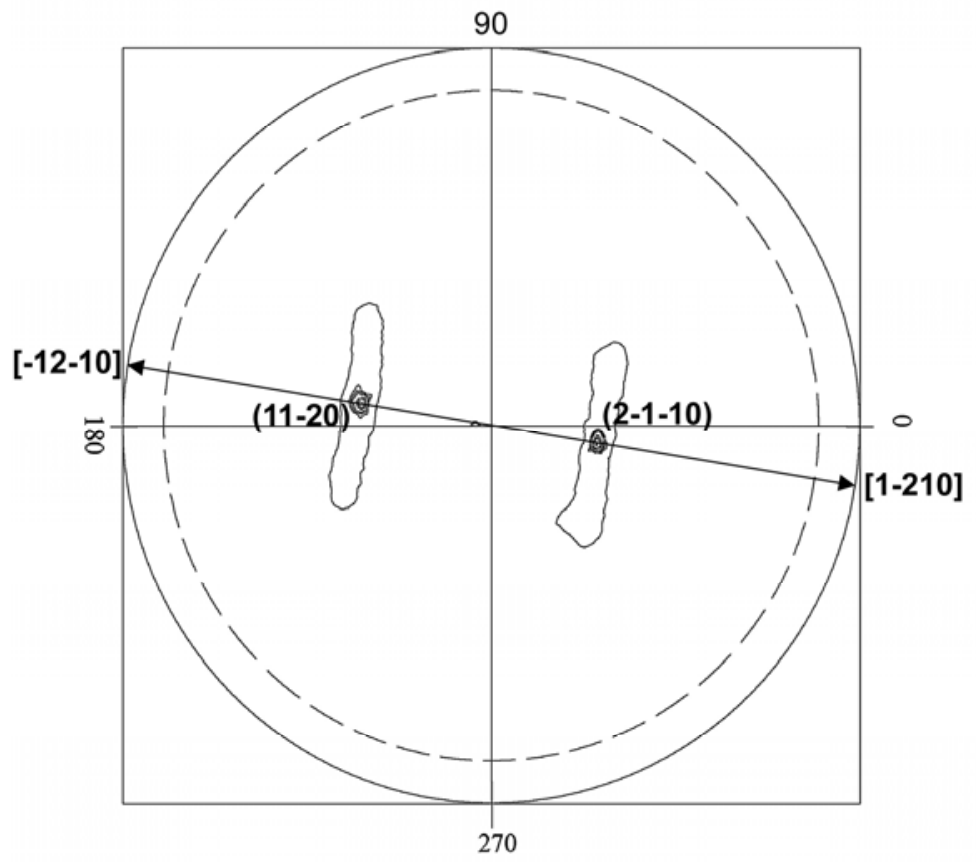

Figure 7. XRD pole figures of $\mathrm{B}_{12} \mathrm{As}_{2}\{110\}$ peaks produced by grains with [100] normal to film surface. 